\title{
Purification and properties of an extracellular $\alpha$-glucosidase from the thermophilic fungus Malbranchea sulfurea
}

\author{
Anil K. Gupta and Sant P. Gautam* \\ Department of BioScience, Rani Durgavati University, Jabalpur 482001 (MP), India \\ (Received 31 July 1992; revised 8 January 1993; accepted 18 January 1993)
}

\begin{abstract}
An extracellular $\alpha$-glucosidase from the thermophilic fungus Malbranchea sulfurea was purified 31.6-fold with a yield of $11.68 \%$. The size of the enzyme was $110 \mathrm{kDa}$. The optimum $\mathrm{pH}$ and temperature for the enzyme activity were $\mathrm{pH} 4.8$ and $60^{\circ} \mathrm{C}$, respectively; the half-life of the activity was $45 \mathrm{~min}$ at $65^{\circ} \mathrm{C}, 125 \mathrm{~min}$ at $60^{\circ} \mathrm{C}$, and $6 \mathrm{~h}$ at $55^{\circ} \mathrm{C}$. The substrate preference of the $\alpha$-glucosidase was $p$-nitrophenyl- $\alpha$-D-glucoside $>$ sucrose $>$ maltose $>$ maltotriose. No activity was recorded against isomaltose, methyl- $\alpha$-D-glucoside and starch.
\end{abstract}

\section{Introduction}

$\alpha$-Glucosidase ( $\alpha$-D-glucoside glucohydrolase, EC 3.2 .1 .20 ) hydrolyses $1,4-\alpha$-glucosidic linkages in oligosaccharides rapidly, relative to such linkages in polysaccharides, which are hydrolysed either slowly or not at all (Saha \& Zeikus, 1991). $\alpha$-Glucosidase is the final enzyme involved in the metabolism of starch to glucose, and is used with $\alpha$-amylase for the saccharification of starch. $\alpha$-Glucosidases are produced by micro-organisms in response to growth on starch-containing medium, and vary widely in their substrate specificity (Kelly \& Fogarty, 1983). Bacterial and fungal $\alpha$-glucosidases are reported to be specific for maltose hydrolysis (Kelly et al., 1987) whereas yeast $\alpha$-glucosidases hydrolyse $p$ nitrophenyl- $\alpha$-D-glucoside at a higher rate than maltose (Kelly \& Fogarty, 1983; Kelly et al., 1987).

The enzymes of thermophilic micro-organisms are of potential industrial importance due to their thermostability. There are many advantages in the use of thermostable enzymes in the starch processing industry, e.g. increased reaction rates and decreased contamination risk (Kelly et al., 1986). High activity and stability at high temperatures are the required features for an ideal amylolytic enzyme; thermophilic micro-organisms are therefore often the first-choice source when looking for a new enzyme (Melasniemi, 1987). Various reports have appeared on the production and characterization of $\alpha$ glucosidase from the thermophilic and hyperthermophilic archaeobacteria (Giblin et al., 1987; Costantino et al., 1990; Saha \& Zeikus, 1991); but no $\alpha$-glucosidases

\footnotetext{
*Author for correspondence.
}

from the thermophilic fungi have yet been described. We recently described the production of extracellular and mycelial $\alpha$-glucosidases, and other amylases, by the thermophilic fungus Malbranchea sulfurea (Gautam \& Gupta, 1992; Gupta \& Gautam, 1992). The present communication reports the purification and properties of an extracellular $\alpha$-glucosidase from $M$. sulfurea.

\section{Methods}

Organism and culture conditions. Malbranchea sulfurea HDBJ AG 30 is a thermophilic fungus, originally isolated from cow dung. It was maintained on the slopes of potato dextrose agar (PDA) medium at $45^{\circ} \mathrm{C}$. The medium for $\alpha$-glucosidase production contained $\left(\mathrm{g}^{-1}\right)$ : soluble starch, 10 ; yeast extract, $4 ; \mathrm{K}_{2} \mathrm{HPO}_{4}, 3 ; \mathrm{MgSO}_{4} \cdot 7 \mathrm{H}_{2} \mathrm{O}, 0.5$. The medium was adjusted to $\mathrm{pH} 7 \cdot 0$, dispensed in $50 \mathrm{ml}$ portions into $250 \mathrm{ml}$ Erlenmeyer flasks, and sterilized by autoclaving at $15 \mathrm{lb}$ for $15 \mathrm{~min}$. The medium in each flask was inoculated with $10^{6}$ conidia of $M$. sulfurea, harvested from 7-d-old cultures grown on PDA medium. The flasks were incubated for $9 \mathrm{~d}$ at $45^{\circ} \mathrm{C}$ without shaking. Mycelia were removed from the culture medium by filtration through Whatman no. 42 filter paper and then Sartorius membrane filter $(0 \cdot 45 \mu \mathrm{m})$. The cellfree culture filtrate was assayed for $\alpha$-glucosidase activity.

$\alpha$-Glucosidase assay. $\alpha$-Glucosidase activity was assayed by measuring the release of glucose from maltose and $p$-nitrophenyl- $\alpha$-D-glucoside (pNPG). The substrates $(1 \%, w / v)$ for the assay were prepared in $0.05 \mathrm{M}$-citrate/phosphate buffer, $\mathrm{pH} 4 \cdot 8$. Assay mixtures contained $1 \mathrm{ml}$ substrate solution and $1 \mathrm{ml}$ enzyme sample. After incubation for $30 \mathrm{~min}$ at $50^{\circ} \mathrm{C}$, the reaction was stopped by keeping the tubes in a steam bath for $15 \mathrm{~min}$ and the liberated glucose was analysed by the glucose-oxidase-peroxidase- $O$-dianisidine method (Hugget \& Nixon, 1955 ). One unit of $\alpha$-glucosidase activity was defined as the amount of enzyme that liberated $1 \mu \mathrm{mol}$ glucose or glucose equivalent $\mathrm{min}^{-1}$ from the appropriate solutions under the above conditions. Protein was measured by the Lowry method using BSA as the standard.

Purification of $\alpha$-glucosidase. All purification steps were carried out at $4{ }^{\circ} \mathrm{C}$. Where needed, the enzyme sample was concentrated by 
Table 1. Summary of purification of $\alpha$-glucosidase from Malbranchea sulfurea

Data are means \pm SEM of four determinations.

\begin{tabular}{clccccc}
\hline \hline $\begin{array}{c}\text { Step } \\
\text { no. }\end{array}$ & Procedure & Protein (mg) & $\begin{array}{c}\text { Enzyme } \\
\text { activity (IU) }\end{array}$ & $\begin{array}{c}\text { Specific activity } \\
\left(\mathrm{IU} \mathrm{mg}^{-1}\right)\end{array}$ & $\begin{array}{c}\text { Purification } \\
\text { (fold) }\end{array}$ & Yield (\%) \\
\hline 1. & $\begin{array}{l}\text { Cell-free } \\
\text { enzyme sample }\end{array}$ & $224 \pm 12.1$ & $28 \pm 1.74$ & $0.125 \pm 0.011$ & - & 100 \\
2. & $\begin{array}{l}\text { Vacuum } \\
\text { concentration } \\
\text { and dialysis }\end{array}$ & $48.004 \pm 3.4$ & $17.325 \pm 1.21$ & $0.3609 \pm 0.041$ & $2.876 \pm 0.484$ & $61.87 \pm 6.7$ \\
3. & $\begin{array}{l}\text { Sephadex G-200 } \\
\text { gel filtration }\end{array}$ & $8.5 \pm 0.4$ & $10.9 \pm 1.04$ & $1.23 \pm 0.101$ & $10.293 \pm 1.3$ & $38.9 \pm 3.6$ \\
4. & $\begin{array}{l}\text { HPLC of } \\
\text { fraction 1 of } \\
\text { Sephadex G-200 } \\
\text { gel filtration }\end{array}$ & $0.83 \pm 0.05$ & $3.26 \pm 0.021$ & $3.95 \pm 0.038$ & $31.6 \pm 4.6$ & $11.68 \pm 0.811$ \\
& & & & & \\
\hline \hline
\end{tabular}

vacuum evaporation at $4{ }^{\circ} \mathrm{C}$. The cell-free enzyme sample was concentrated ten-fold and dialysed for $24 \mathrm{~h}$ against $0.05 \mathrm{M}$-citrate/ phosphate buffer, $\mathrm{pH} 5.0$. The concentrated and dialysed enzyme sample was applied to a Sephadex G-200 column $(1.56 \times 50 \mathrm{~cm}$, void volume $28.2 \mathrm{ml}$ ) and eluted at $6 \mathrm{ml} \mathrm{h}^{-1}$ with degassed and filtered $0.05 \mathrm{M}$-citrate/phosphate buffer, $\mathrm{pH} 5.0$. Fractions of $2.2 \mathrm{ml}$ volume were collected. The active $\alpha$-glucosidase fractions were pooled and concentrated by vacuum evaporation to a final volume of $2.0 \mathrm{ml}$. The concentrated enzyme sample thus obtained was applied to a Waters Protein Pack HPLC P 300 column ( $20 \mu$ injection), and eluted with 0.05 M-citrate/phosphate buffer, $\mathrm{pH} 5 \cdot 0$. The HPLC separation was repeated until sufficient purified enzyme was obtained. The active $\alpha$ glucosidase fractions were pooled and concentrated by vacuum evaporation.

SDS-PAGE and molecular mass determination. The homogeneity of the $\alpha$-glucosidase preparation obtained after HPLC was determined by SDS-PAGE on $7.5 \%(\mathrm{w} / \mathrm{v})$ gel (Weber \& Osborn, 1975). The molecular mass of the purified $\alpha$-glucosidase was also determined by SDS-PAGE. The following proteins were used for calibration: phosphorylase $\mathrm{b}(97.4 \mathrm{kDa})$, bovine serum albumin $(66 \mathrm{kDa})$, chicken egg albumin $(45 \mathrm{kDa})$, carbonic anhydrase $(29 \mathrm{kDa})$, and lactalbumin $(14 \cdot 2 \mathrm{kDa})$.

The experiments were repeated at least four times and the data presented here are the arithmetic mean of the observations.

Chemicals were of analytical reagent grade, purchased from Sigma, BDH, Hi-media (India) and Loba (India). Sephadex G-200 (superfine) was from Pharmacia; dialysis bags were from Sigma.

\section{Results and Discussion}

\section{Purification of the $\alpha$-glucosidase}

A summary is presented in Table 1 . Gel filtration of the concentrated and dialysed enzyme sample through Sephadex G-200 resulted in two protein peaks. $\alpha$ Glucosidase activity was recorded in the fractions corresponding to protein peak I, while protein peak II showed no $\alpha$-glucosidase or maltase activity (Fig. 1). HPLC of the concentrated $\alpha$-glucosidase fractions obtained after passage through Sephadex G-200 resulted in four protein peaks. The $\alpha$-glucosidase activity was

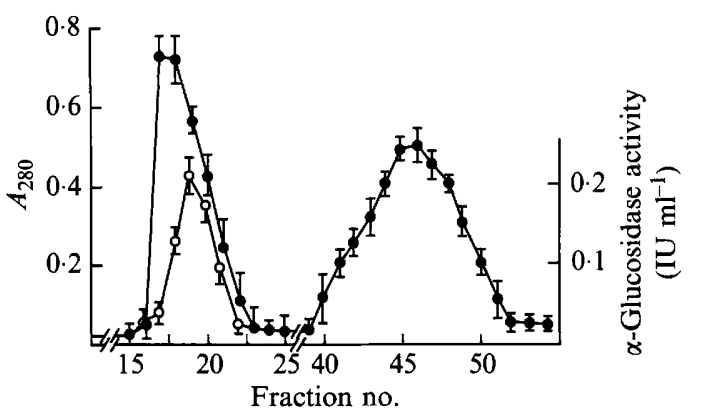

Fig. 1. Gel filtration of the concentrated and dialysed $\alpha$-glucosidase preparation from Sephadex G-200 column $(1.56 \times 50 \mathrm{~cm})$. The protein was eluted with $0.05 \mathrm{M}$-citrate/phosphate buffer, $\mathrm{pH} 5.0$, and $2.2 \mathrm{ml}$ fractions were collected. $\bigcirc$, Absorbance at $280 \mathrm{~nm} ; \bigcirc, \alpha$-glucosidase activity. Error bars are SEM from at least four observations.

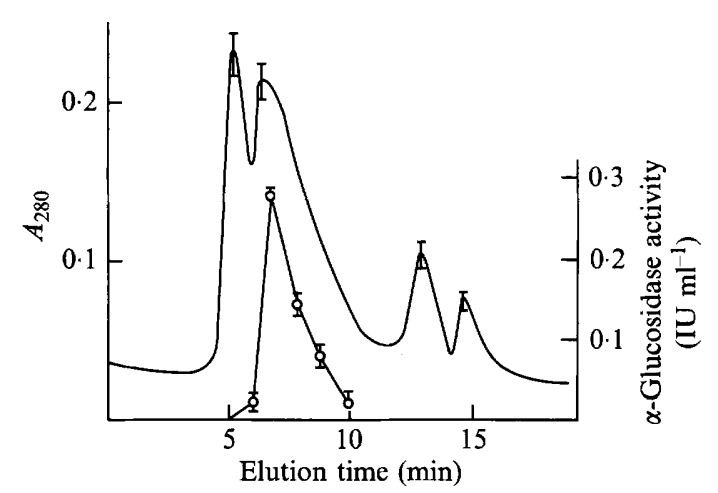

Fig. 2. HPLC of the $\alpha$-glucosidase fractions obtained from the Sephadex G-200 column, pooled and concentrated by vacuum evaporation. Twenty $\mu \mathrm{l}$ of the concentrated enzyme preparation was injected, and eluted with $0.05 \mathrm{M}$-citrate/phosphate buffer, pH 5.0. Proteins were monitored as $A_{280}(-)$. $\bigcirc, \alpha$-Glucosidase activity. Error bars are SEM from at least four observations.

detected in fractions corresponding to protein peak II (Fig. 2). The $\alpha$-glucosidase was purified $31 \cdot 6$-fold with $11.68 \%$ yield. Considering that the enzyme production 


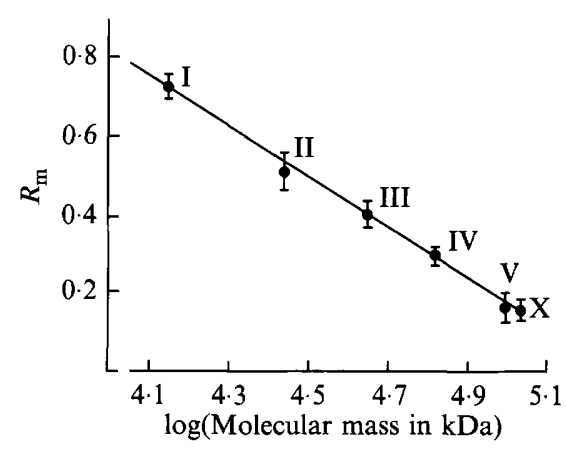

Fig. 3. Estimation of molecular mass of the $M$. sulfurea $\alpha$-glucosidase by SDS-PAGE. Protein standards were: I, lactalbumin (14.2 kDa); II, carbonic anhydrase $(29 \mathrm{kDa})$; III, chicken egg albumin $(45 \mathrm{kDa})$; IV, bovine serum albumin $(66 \mathrm{kDa}) ; \mathrm{V}$, phosphorylase b $(97.4 \mathrm{kDa}) ; \mathrm{X}, \alpha-$ glucosidase from $M$. sulfurea $(110 \mathrm{kDa}) .50 \mu \mathrm{l}$ purified enzyme $(25 \mu \mathrm{g}$ protein) was applied to the gel. Electrophoresis was for $4 \mathrm{~h}$ at a constant current of $8 \mathrm{~mA}$. The gel was stained with Coomassie brilliant blue stain. Error bars are SEM of four observations.

medium contained $4 \mathrm{~g}^{-1}$ yeast extract, the purification achieved here is very low. The low purification factor may be due to the fact that the fungus was grown in the medium for $9 \mathrm{~d}$, during which time the fungus is expected to utilize most of the supplemented yeast extract. The crude $\alpha$-glucosidase thus obtained may have very low amounts of the yeast extract and other proteins to be separated, which would be a possible reason for the low purification factor achieved. SDS-PAGE of the preparation obtained after HPLC resulted in only one protein band, indicating homogeneity of the purified enzyme. The molecular mass of the purified enzyme was estimated as $110 \pm 0 \cdot 15 \mathrm{kDa}$ by SDS-PAGE (Fig. 3). The molecular masses of most reported microbial $\alpha$-glucosidases are below $70 \mathrm{kDa}$ (Kelly \& Fogarty, 1983); however, $\alpha$-glucosidases of high molecular mass (125 kDa, $130 \mathrm{kDa}$ and $140 \mathrm{kDa}$ ) have been reported in Aspergillus awamori (Yamasaki et al., 1977).

\section{Activity and stability of the enzyme}

The $\alpha$-glucosidase showed maximum activity at $\mathrm{pH} 4 \cdot 8$, and was stable at $\mathrm{pH} 4-5.8$ (Fig. 4). In general, the reported $\mathrm{pH}$ optima of fungal $\alpha$-glucosidases have been in the region of 3.5-5.0, whereas $\mathrm{pH}$ optima of yeast $\alpha$ glucosidases tend to be in the range 6.5-7.0 (Kelly \& Fogarty, 1983). The enzyme showed maximal activity at $60{ }^{\circ} \mathrm{C}$. The half life of the $\alpha$-glucosidase was $6 \mathrm{~h}$ at $55^{\circ} \mathrm{C}$, $125 \mathrm{~min}$ at $60^{\circ} \mathrm{C}$ and $45 \mathrm{~min}$ at $65^{\circ} \mathrm{C}$ (Fig. 5). The temperature optima $\left(60^{\circ} \mathrm{C}\right)$ resembles that of Lipomyces starkeyi $\alpha$-glucosidase (Kelly et al., 1985). In various other fungal $\alpha$-glucosidases, the temperature optimum has been $50-55^{\circ} \mathrm{C}$ (Kelly \& Fogarty, 1983). Costantino et al. (1990) recorded a broad temperature optimum of

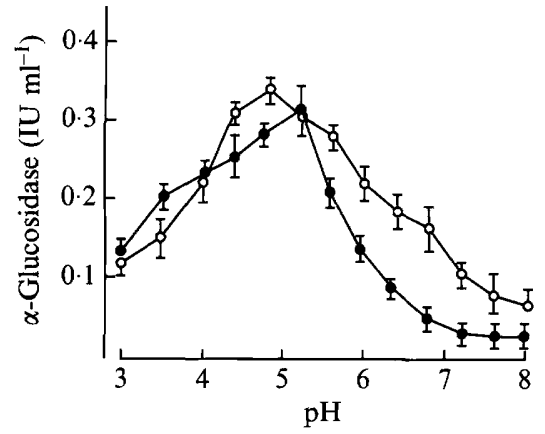

Fig. 4. Effect of $\mathrm{pH}$ on activity and stability of the $\alpha$-glucosidase. Enzyme activity was determined at $60^{\circ} \mathrm{C}$ using the following buffer systems: citrate at $\mathrm{pH} 3 \cdot 0-5 \cdot 0$, phosphate at $\mathrm{pH} 5.5$ to $7 \cdot 5$, and borate at $\mathrm{pH} 8.0$. To determine $\mathrm{pH}$ stability, the enzyme preparations were kept at $4{ }^{\circ} \mathrm{C}$ for $24 \mathrm{~h}$, with buffers $\mathrm{pH} 3 \cdot 0-8.0$ and enzyme activity was measured thereafter at $\mathrm{pH} 4.8$ and $60^{\circ} \mathrm{C}$. $\mathrm{O}$, Activity; $\bigcirc$, stability. Error bars are SEM of four observations.

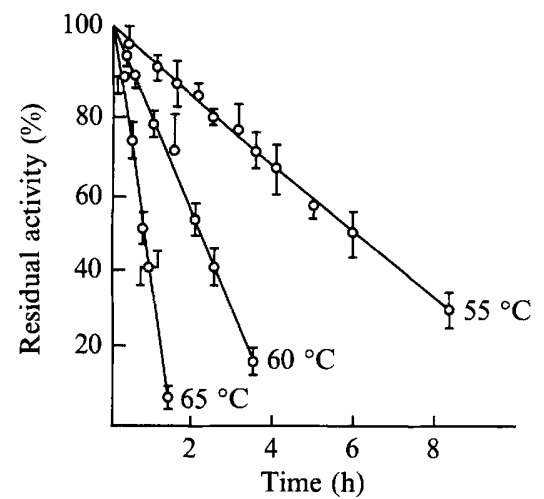

Fig. 5. Effect of temperature on $\alpha$-glucosidase stability. The enzyme was incubated in citrate buffer ( $\mathrm{pH} 4.8)$ at various temperatures, and residual activity was measured at various time intervals described in the text. Error bars are SEM of four observations.

about $105-115^{\circ} \mathrm{C}$ for Pyrococcus furiosus $\alpha$-glucosidase, which is the highest temperature optimum recorded for a purified enzyme.

\section{Catalytic properties}

Table 2 shows relative rates of hydrolysis of various substrate by $M$. sulfurea $\alpha$-glucosidase. The $\alpha$-glucosidase hydrolysed pNPG at the highest rate; sucrose, maltose and maltotriose were hydrolysed at $31 \%, 12 \%$ and $7 \cdot 2 \%$ of this rate, respectively. Isomaltose, methyl- $\alpha$-Dglucoside and starch were not hydrolysed by the $\alpha$-glucosidase. In its substrate specificity, $M$. sulfurea $\alpha$-glucosidase showed most similarity to the yeast $\alpha$-glucosidase, which hydrolyses sucrose more rapidly than maltose and pNPG more rapidly than either. Sucrose-hydrolysing activity was found to be associated with electrophoretically homogenous $M$. sulfurea $\alpha$ - 
Table 2. Substrate specificity of the purified $\alpha-$ glucosidase from $M$. sulfurea

Results are expressed as the arithmetic mean \pm SEM of four observations. Activities are expressed relative to the pNPG $\alpha$ glucosidase activity of $0.35 \pm 0.02 \mathrm{U}$ under standard assay conditions. Substrates tested without significnt activity (less than $5 \%$ ) were: $\alpha$-methyl-D-glucoside, isomaltose and starch. Experimental methods are described in the text.

\begin{tabular}{lc}
\hline \hline Substrate & Hydrolysis (\%) \\
\hline$p$-Nitrophenyl- $\alpha$-D-glucopyranoside & $100 \pm 2.5$ \\
Sucrose & $31 \pm 1 \cdot 1$ \\
Maltose & $12 \pm 0.76$ \\
Maltotriose & $7.2 \pm 0.66$ \\
\hline \hline
\end{tabular}

Table 3. Inhibitory effects of various chemicals on the activity of $M$. sulfurea $\alpha$-glucosidase

Results are expressed as the arithmetic mean \pm SEM of four observations. Chloride salts $(10 \mathrm{mM})$ of $\mathrm{Cu}^{2+}, \mathrm{Hg}^{\frac{1}{2+}}, \mathrm{Mg}^{2+}, \mathrm{Zn}^{2+}$, $\mathrm{Ca}^{2+}$ and $\mathrm{Ag}^{+}$were supplemented separately in the enzyme assay mixtures. The $\alpha$-glucosidase assay is described in the text. The $100 \%$ activity corresponds to $0.35 \pm 0.014 \mathrm{U} \alpha$-glucosidase activity under the standard assay conditions.

\begin{tabular}{lc}
\hline \hline Substance & $\begin{array}{c}\text { Residual activity } \\
(\%)\end{array}$ \\
\hline $\mathrm{Cu}^{2+}(10 \mathrm{mM})$ & $84 \cdot 36 \pm 5 \cdot 3$ \\
$\mathrm{Mg}^{2+}(10 \mathrm{~mm})$ & $100 \pm 7 \cdot 2$ \\
$\mathrm{Zn}^{2+}(10 \mathrm{mM})$ & $100 \pm 4 \cdot 6$ \\
$\mathrm{Hg}^{2+}(10 \mathrm{mM})$ & $64 \pm 7 \cdot 4$ \\
$\mathrm{Ca}^{2+}(10 \mathrm{mM})$ & $111 \pm 12 \cdot 12$ \\
$\mathrm{Ag}^{+}(10 \mathrm{mM})$ & $58 \cdot 61 \pm 6 \cdot 22$ \\
$\mathrm{EDTA}(25 \mathrm{mM})$ & $86 \cdot 23 \pm 7 \cdot 3$ \\
Histidine $(10 \mathrm{mM})$ & $100 \pm 8 \cdot 3$ \\
2-Mercaptoethanol (2 mM) & $130 \pm 15 \cdot 4$ \\
$p$-Chloromercuribenzoate & $66 \cdot 86 \pm 7 \cdot 8$ \\
\hline \hline
\end{tabular}

glucosidase. It indicates that hydrolysis of $\alpha-1,2$ linkages by an $\alpha-1,4$ linkage-specific $\alpha$-glucosidase is not unusual. Most yeast $\alpha$-glucosidases hydrolyse sucrose more slowly than pNPG (Chiba et al., 1973). Highly purified maltase and $\alpha$-glucosidase preparations from Bacillus amyloliquefaciens and Bacillus licheniformis, respectively, hydrolyse $\alpha-1,2$ linkages in sucrose (Fogarty et al., 1985; Kelly et al., 1986). The $M$. sulfurea $\alpha$-glucosidase resembles Bacillus amyloliquefaciens $\alpha$-glucosidase (Fogarty et al., 1985) in its inability to hydrolyse isomaltose. It supports the conclusion of Fogarty et al. (1985) that for a single enzyme to hydrolyse $\alpha-1,4$ and $\alpha-1,6$ glucosidic linkages is not as common as was previously supposed (Wang \& Hartman, 1973).

The effects of various chemicals on the $\alpha$-glucosidase activity were tested. $\mathrm{Hg}^{2+}, \mathrm{Cu}^{2+}, \mathrm{Ag}^{+}$and $p$-chloromercuribenzoate exerted inhibitory effects, whereas 2mercaptoethanol enhanced enzyme activity (Table 3 ). Inactivation by $\mathrm{Cu}^{2+}$ and $\mathrm{Hg}^{2+}$ is indicative of the presence of thiol groups, carboxyl groups, or histidine residues in the enzyme molecule (Kundu \& Das, 1970). Inhibition by $p$-chloromercuribenzoate indicates that cysteine is involved at the active site. Addition of 2mercaptoethanol increased enzyme activity, indicating the presence of oxidation-sensitive thiol groups on the enzyme (Plant et al., 1988). EDTA (25 mM) had no significant effect on the enzyme activity, suggesting that metal ions are not important to the enzyme activity.

The extracellular $\alpha$-glucosidase from the thermophilic fungus $M$. sulfurea is distinct from other fungal $\alpha$-glucosidases in its substrate specificity. The purified $\alpha$-glucosidase showed hydrolysis of $\alpha-1,2$ linkages as an inherent property.

The authors are grateful to Professor S. K. Hasija, Rani Durgavati University, Jabalpur for providing excellent laboratory facilities, to Professor G. P. Agarwal for encouragement and to the Madhya Pradesh Council of Science \& Technology for financial assistance and laboratory facilities.

\section{References}

Chiba, S., Saeki, T. \& Shimomura, T. (1973). Substrate specificity of Saccharomyces cerevisiae $\alpha$-glucosidase. Agriculture and Biological Chemistry 37, 1831-1837.

Costantino, H. R., Brown, S. H. \& Kelly, R. M. (1990). Purification and characterization of an $\alpha$-glucosidase from a hyperthermophilic archaebacterium Pyrococcus furiosus, exhibiting a temperature optima of $105^{\circ} \mathrm{C}-115^{\circ} \mathrm{C}$. Journal of Bacteriology 172, 3654-3660.

Fogarty, W. M., Kelly, C. T. \& KadaM, S. K. (1985). Separation and characterization of an $\alpha$-glucosidase and maltase from Bacillus amyloliquefaciens. Canadian Journal of Microbiology 31, 670-674.

Gautam, S. P. \& GuPTA, A. K. (1992). Extracellular and mycelial amylases of the thermophilic fungus Malbranchea sulfurea. Mycopathologia 119, 77-82.

Giblin, M., Kelly, C. T. \& Fogarty, W. M. (1987). Thermostable $\alpha$ glucosidase produced by Bacillus caldovelox DSM 411. Canadian Journal of Microbiology 33, 614-618.

Gupta, A. K. \& Gautam, S. P. (1992). Production of extracellular amylases by the thermophilic and thermotolerant fungi. Cryptogamic Botany (In the Press).

HugGet, A. S. C. \& Nixon, D. A. (1955). Glucose oxidase method for measurement of glucose. Biochemistry Journal 60, 12-19.

Kelly, C. T. \& FogarTy, W. M. (1983). Microbial $\alpha$-glucosidases. Process Biochemistry 18(3), 6-12.

Kelly, C. T., Moriarity, M. E. \& Fogarty, W. M. (1985). Thermostable extracellular $\alpha$-amylase and $\alpha$-glucosidase of Lipomyces starkeyi. Applied Microbiology and Biotechnology 22, 352-358.

Kelly, C. T., Giblin, M. \& FogarTy, W. M. (1986). Resolution, purification, and characterization of two extracellular glucohydrolases, $\alpha$-glucosidase and maltase of Bacillus licheniformis. Canadian Journal of Microbiology 32, 342-347.

Kelly, C. T., Brennan, P. A. \& Fogarty, W. M. (1987). Resolution of the extracellular $\alpha$-glucosidase system of Bacillus sp. NCIB 11203. Biotechnology Letters 9(2), 125-130.

Kundu, A. K. \& DAS, S. (1970). Production of amylase in liquid culture by a strain of Aspergillus oryzae. Applied Microbiology 19(4), 598-603.

Melasniemi, H. (1987). Effect of carbon sources on production of thermostable $\alpha$-amylase, pullulanase and $\alpha$-glucosidase by Clostridium thermohydrosulfuricum. Journal of General Microbiology 133, 883-890.

Plant, A. R., Parratt, S., Daniel, R. M. \& Morgan, W. M. (1988). A cell-associated oligo-1,6- $\alpha$-glucosidase from an extremely thermophilic anaerobic bacterium, Thermoanaerobium Tok 6-B i. Biochemistry Journal 255, 865-868.

SAHA, B. C. \& ZeIKUS, J. G. (1991). Characterization of a thermostable 
$\alpha$-glucosidase from Clostridium thermohydrosulfuricum 39 E. Applied Microbiology and Biotechnology 35, 568-571.

Wang, L. H. \& Hartman, P. A. (1976). Purification and some properties of an extracellular maltase from Bacillus subtilis. Applied and Environmental Microbiology 31, 108-118.

Weber, R. \& Osborn, M. (1975). Proteins and sodium dodecyl sulfate, molecular weight determination on polyacrylamide gel and related procedures. In The Proteins, vol. I, pp. 79-233. Edited by $\mathrm{H}$ Neurath, R. C. Hill \& C. Border. Academic Press: New York.

YamaSAKI, Y., SUZUKI, V. \& OzaWA, J. (1977). Three forms of $\alpha$ glucosidase and glucoamylase from Aspergillus awamori. Agricultural and Biological Chemistry 41, 2149-2161. 